\title{
ECONOMIC SIGNIFICANCE, NUTRITIONAL VALUE AND APPLICATION OF TRITICALE
}

\author{
Violeta Babićl, Vera Rajičićn ${ }^{2}$, Nenad Đurić3 \\ *Corresponding author E-mail: verarajicic74@gmail.com
}

A R T I C L E I N F O
Review Article
Received: 15 September 2021
Accepted: 29 November 2021
doi:10.5937/ekoPolj2104089B
UDC 636.085.2:[
633.11+633.14 ]

Keywords:

economic significance, chemical composition, diet, triticale

JEL: $Q 180$

\begin{abstract}
A B S T R A C T
Triticale is a new type of real grain, which was created by the breeding and selection of a man. This species deserves more and more attention from both domestic producers and producers on a global scale because it encompassed all the positive properties of wheat and rye. The paper clearly presents the knowledge about the importance, nutritional value and application of triticale and the effect of its usage in a diet of monogastric animals. The variety of uses, appropriate chemical composition, acceptable and studied breeding technology, classifies triticale as an irreplaceable source of energy and protein needs of animals. Due to its multiple usages: for grain, fodder and as a raw material for biofuel, contributes to the economic sustainability of crop production. The needs of this plant at the level of agrotechnical investments are less than in other cereals, so triticale is increasingly presented in organic and sustainable agricultural production.
\end{abstract}

(C) 2021 EA. All rights reserved.

\section{Introduction}

Triticale as a new type of small grain was created by crossbreeding wheat and rye. The first triticale hybrids are thought to have originated in Scotland in 1875 (Stallknecht et al., 1996). The same authors point out that the first genotypes obtained by crossing wheat and rye were sterile, while the first fertile ones originated in Germany in 1888. The name triticale was first mentioned in literature in 1935 in Germany.

1 Violeta Babić, Ph.D, Assistant Professor, University of Niš, Faculty of Agriculture, Kosančićeva 4, 37000 Kruševac, Serbia. Phone: +381 6064545 45, E-mail: babic.violeta@ ni.ac.rs, ORCID ID (https://orcid.org/0000-0001-9536-973X)

2 Vera Rajičić, Ph.D, Assistant Professor, Principal Research Fellow, University of Niš, Faculty of Agriculture, Kosančićeva 4, 37000 Kruševac, Serbia. Phone: +381 6522932 55, E-mail: verarajicic74@gmail.com, ORCID ID (https://orcid.org/0000-0002-4468-7073)

3 Nenad Đurić, Ph.D, Senior Research Fellow, Associate Professor, Institute for vegetable crops, Karađorđeva 71, 11420 Smederevska Palanka, Serbia. Phone: +381 628035360 , E-mail: nenad.djuric@outlook.com, ORCID ID (https://orcid.org/0000-0001-5048-454X) 
Triticale presents a plant hybrid species, a new botanical genus in the family Poaceae, created by a man, with a tendency to combine the positive characteristics of wheat and rye. Progress in the selection and breeding of winter triticale depends on the available genetic variability, the manner of incorporation of desirable genes into superior genotypes, as well as the efficiency of selected (chosen) genotypes, lines (Ivanova and Tsenov, 2014; Milovanović et al., 2014; Đurić et al., 2015; Derejko et al., 2020).

Triticale as a new very successful type of small grain, which in the previous decades has deserved more and more attention, is becoming more and more represented and important, both among our producers and in the world. Nowadays, thanks to the intensive breeding program, especially in the Center for Small Grains in Kragujevac, there are new domestic commercial brands on the brand lists. They are characterized by a whole range of good agronomic traits, which contribute to this species becoming more attractive and occupy larger areas (Milovanović et al., 2014; Terzić et al., 2018; Đekić (Rajičić) et al., 2019; Rajičić et al., 2020b). The first domestic varieties of winter and spring triticale were created in Kragujevac (1980 and 1987), and this is the result of the fact that intergenus hybridization in the Center for Small Grains has been intensively worked on since 1960. They are characterized by a whole range of good agronomic qualities, which contribute to this species becoming more attractive and occupy larger areas. Milovanovic et al. (2007a), point out that the triticale is grown worldwide on areas over 4 million hectares. Areas under this brand are constantly increasing, so they have tripled in the past ten years. The largest areas under triticale are in Poland, Germany, Russia, the USA, China, France and Hungary. In these countries, the sown areas reached 100.000 to 700.000 ha (Benbelkacem, 2002). In Serbia, triticale is grown on 19.482 ha (mainly winter varieties) with an average yield of $4.14 \mathrm{t} / \mathrm{ha}$, with an increasing trend of areas, so that it entered the ranks of important field plants (Rajičić et al., 2020a). Triticale is a relatively new plant species in our area, and it has only been intensively cultivated for about 20 years. In Central and Southeastern Europe, it is grown mostly in Poland (up to one million ha), and it occupies significant areas in Hungary and Ukraine. Although production has also started in Romania, which has significant areas under small grains, satisfactory results have not been achieved because winter wheat still has an advantage (Saulescu et al., 1998). Today in the world, based on data from the FAO organization in 2019, triticale is grown annually on an area of 3.808 mill. ha with an average grain yield of $3.69 \mathrm{t} /$ ha. In 2019 , triticale while in the Republic of Serbia it is grown on an area of 25.725 ha, with a slightly higher grain yields of $3.97 \mathrm{t} / \mathrm{ha}$ (FAO, 2021).

\section{The significance of triticale and its prevalence}

The newer brands of triticale generally reached the leading wheat sorts in terms of grain yield, while they surpassed rye, barley and oats cultivars (Milovanović et al., 2014). As a species, it showed high adaptability in our environmental and soil conditions, which caused the obtaining of stable yields. It showed high tolerance to acid soils, as well as good production results on sandy soils (Rajičić et al., 2020a). It showed a similar 
advantage in terms of drought tolerance. It can be said that it inherited from his parental species a very good to excellent tolerance to the most important pathogens and pests of small grains.

Early ripening, resistance to lodging and drought, lower stems, high and stable grain yield are some of the characteristics of $\mathrm{KG}$ varieties of triticale transferred from wheat, as a second parent (Milovanović et al., 2006). Today, triticale is mostly used as a granular nutrient in the diet of monogastric animals, especially in the diet of pigs and poultry while in recent times it is increasingly used for silage (Djekic et al., 2011; Đekić et al., 2012a; b).

Experiments in different countries have shown that triticale grain, if not contaminated with carob or fusarium, has similar nutritional values to wheat, and is superior to barley (Milovanović et al., 2014). The same authors also state that the high sugar content in the green mass of triticale provides a high nutritional value of the crop, and the large production of biomass allows it to be used as a fodder plant and replace other traditional crops such as rye and oats. In the United States, autumn and spring triticale crops are used to graze livestock. Mowing winter triticale in the spring before the outbreak of the first knee enables obtaining additional fodder, and it even has a favorable effect on the crop, since it reduces the danger of lodging (Đekić et al., 2018b). High and late brands are used for green mass. The yields of the green mass reach 20 to $60 \mathrm{t} / \mathrm{ha}$. It can be used as hay, ground hay or for preparing silage. The potential of triticale, grown under optimal conditions, in terms of yield is close to the potential of wheat and is much higher than the potential of wheat under unfavorable growing conditions (Milovanović et al., 2011).

Triticale as a new plant species is quite tolerant to later sowing dates. Increasing the sowing norm without grounds contributes to the reduction of vegetation space, greater competition between plants for food and water. As a consequence of this condition, the size of the ears decreases, the number of grains per class and the physical indicators of grain quality decrease (weight of 1000 grains and volume weight). The current assortment of triticale is resistant to low temperatures, and the causes of the deterioration of certain surfaces are often shallow sowing, lack of rolling and late sowing dates (Ivanova and Tsenov, 2014; Kendal et al., 2016; Lalevic and Biberdzic, 2016; Bielski, and Falkowski, 2017; Madić et al., 2018; Derejko et al., 2020). Only tolerant triticale genotypes with optimal plant composition and well-developed roots can withstand air and soil drought (Djekic et al., 2011; Kirchev and Georgieva, 2017; Bielski et al., 2020).

\section{Production properties and quality of triticale}

Grain yield per unit area is one of the most important factors influencing the profitability and economy of production. Grain yield, 1000 grain mass and hectolitre mass are complex quantitative properties conditioned by the action of a large number of genes under the strong influence of the external environment. 
According to Milovanović et al. (2014), the mass of 1000 grains in triticale ranges from 40-65 g, while the bulk density ranges from 65 to $75 \mathrm{~kg}$. Milovanović et al. (2006), examining the winter variety of triticale Favorit, in a three-year period (1998-2000), point out that the average weight of 1000 grains was $44.1 \mathrm{~g}$. The same authors noticed that Favorit achieved a significantly higher average grain yield $(7.21 \mathrm{t} / \mathrm{ha})$ compared to the standard variety $\mathrm{Kg} 20$ (6.45 t/ha), ie $760 \mathrm{~kg} / \mathrm{ha}$ more. Such a high yield is accompanied by good technological properties of the grain, especially hectolitre mass, mass of 1000 grains, protein content and the number of falls according to Hagberg.

Perišić et al. (2008), studied the winter triticale variety General. Compared to the older varieties, which are widespread in production, the General variety is characterized by a higher and more stable grain yield. In a two-year period, the General variety achieved a statistical and highly important greater grain yield (6.78 tha) compared to the $\mathrm{Kg} 20$ standard (5.77 t/ha). The protein content in the grain of the General variety averaged $14.6 \%$. Milovanović et al. (2007a), state that the new variety of winter triticale Knjaz is lower in comparison with the standard $(\mathrm{Kg} 20)$ by $11 \mathrm{~cm}$ and that it is more resistant to lodging. In addition, the Knjaz variety is 3.4 days earlier than the standard. All this makes the variety Knjaz so far the lowest recognized, the earliest and the most resistant to lodging genotype in our country and more broadly. In addition, the Knjaz variety is characterized by high resistance to the causes of stem rust and powdery mildew, which is a general characteristic of triticale. It is slightly shrunken and medium-sized grain with a mass of 1000 grains of about $36 \mathrm{~g}$. More than $93 \%$ of Knjaz grains belong to large fractions (above $2.5 \mathrm{~mm}$ ). In terms of grain yield, it also surpassed the $\mathrm{Kg} 20$ variety, but the differences were not statistically justified. It is a very fertile variety with wide yield adaptability. It achieved the highest yield in Zajecar ( $8.36 \mathrm{t} / \mathrm{ha}$ ) in the experiments of the Commission, but it showed the genetic potential for grain yield in the experiments in Kragujevac and in the field, around 11 t/ha. The coefficient of variation for yield was lower in the variety Knjaz in relation to the standard, indicating better stability of the yield of this new variety. Based on all this, Knjaz variety was recognized by the Variety Commission in 1996.

Milovanović et al. (2009a), studying the winter variety of triticale Žarko, point out another in a series of Kragujevac varieties of winter triticale with excellent agronomic, physiological and technological characteristics. Thanks to a good genetic basis, favorable climate conditions and their interaction, the variety Žarko achieved a significantly higher grain yield of $8.36 \mathrm{t} / \mathrm{ha}$, which is $783 \mathrm{~kg} / \mathrm{ha}$ more than the standard variety $\mathrm{Kg} 20$ (7.57 t/ha). Observing the localities and years, the variety Žarko achieved the highest grain yield of $9.97 \mathrm{t} /$ ha in the 2004/2005 in Sremska Mitrovica. The weight of 1000 grains is about $36 \mathrm{~g}$, and the bulk density is about $82 \mathrm{~kg}$, which is more than the standard. The same authors point out that this variety has a high value of usage, ie it can be used for haylage and silage, or for feeding livestock in the form of concentrated nutrients. In the human diet, it can be used to produce rye-type bread.

Đekić (2010) they studied three winter hexaploid varieties of triticale of Kragujevac (Kg 20, Favorit and Trijumf). The best indicator of yield and grain quality in class width, number of grains per class, grain weight, grain yield per plant and grain weight 
per class was achieved by the examined variety Favorit, and in plant height and class length by the Triumph variety. The standard variety $(\mathrm{Kg} 20)$ had the highest number of spikes in the class. The analysis of the obtained data revealed a significant dependence of the examined components of grain quality on the genotype. It was found that there were very significant differences in plant height, spike width and number of grains per spike between the tested triticale cultivars $(\mathrm{P}<0.01)$. The determined difference in significance between the examined triticale cultivars was important for the length of classes and grain weight per plant. No significant differences in grain weight, number of spikelets per spike and grain yield per plant were found between the examined triticale varieties.

During the two-year study, Đekić et al. (2014a), they camo to conclusion that the highest grain yield was achieved by the variety Trijumf (5.01 t/ha). The highest two-year mean value of 1000 grains was achieved by the Favorit variety (44.02 g), and the smallest by the variety $\mathrm{Kg} 20$ (41.10 g). The average two-year value of hectolitre mass was the highest in the varieties Favorit and Trijumf and its walue was $65.47 \mathrm{~kg} / \mathrm{hl}$. The analysis of variance statistically determined very significant and important differences for grain yield and weight of 1000 grains between the examined years, ie environmental factors. The interaction of the examined factors (year x genotype) had a statistically very significant influence on the yield and a significant influence on the mass of 1000 grains, which indicated that the examined factors mutually had reinforced their effect.

During one decade of winter triticale breeding, two varieties ( $P K B$ Vožd and PKB Kardinal) of good agronomic and technological properties were created at the PKB Agroekonomik Institute (Đurić et al., 2011; 2015). The variety PKB Kardinal achieved a completely satisfactory yield of an average of $8.0 \mathrm{t} / \mathrm{ha}$ of grain in all localities and in different years from the aspect of climate, and can be recommended for the current assortment of triticale in the Republic of Serbia.

The results of three years of research on four different varieties of triticale in the Center for Small Grains in Kragujevac, Đekić et al. (2014b) indicate that all examined varieties showed a high degree of adaptability in grain yield, weight of 1000 grains and hectolitre weight, which suggested that as such they can be of great importance in large-scale production of triticale in agricultural conditions of Serbia. During the three-year trial, the highest grain yield was achieved by the KG Tempo and Trijumf variety $(5.38 \mathrm{t} / \mathrm{ha}$ and $5.31 \mathrm{t} / \mathrm{ha})$. The highest three-year average value of 1000 grains was achieved by the $K G$ Tempo variety (45.03 g), and the smallest by the $K g 20$ variety $(42.11 \mathrm{~g})$. The average three-year value of hectolitre mass was the highest in the variety $K G$ Tempo and its walue was $66.56 \mathrm{~kg} / \mathrm{hl}$. Analysis of variance revealed statistically very highly significant and very important differences for grain yield and weight of 1000 grains between the examined years, while the interaction of the examined factors was statistically very highly significant for yield and weight of 1000 grains, indicating that the examined factors mutually reinforced their effect. 
Lalević et al. (2012), showed a significant variation in grain yield and its quality depending on the genotype, years and the dose of fertilization. In both years of testing, the winter triticale variety $\mathrm{Kg} 20$ achieved a significantly higher grain yield (5.99 t/ha) compared to the other tested variety, Favorit (5.16 t/ha). Differences in yield between the tested fertilization variants were statistically justified, the amount of $80 \mathrm{~kg} / \mathrm{ha}$ of nitrogen, $100 \mathrm{~kg} / \mathrm{ha}$ of phosphorus and $60 \mathrm{~kg} / \mathrm{ha}$ of potassium, Rajičić et al. (2020a) recommend both as optimal and as the most profitable for use in large-scale production. Due to the poor filling of triticale grains, one of the disadvantages of this culture was the small hectoliter mass, which prevented the full realization of the genetic potential for the yield. On average, the hectoliter mass was significantly much higher in $2015(83.81 \mathrm{~kg} / \mathrm{hl})$ compared to $2014(69.03 \mathrm{~kg} / \mathrm{hl})$. Terzic et al. (2018) examined the studies with a higher nitrogen dose of $120 \mathrm{~kg} / \mathrm{ha}$ on yield and yield parameters. They found that the hectoliter mass during the three-year study varied from $68.21 \mathrm{~kg} / \mathrm{hl}$ in the control variant to 69.89 $\mathrm{kg} / \mathrm{hl}$ in the fertilized variant with $120 \mathrm{~kg} / \mathrm{ha}$ of nitrogen, $100 \mathrm{~kg} / \mathrm{ha}$ of phosphorus and $60 \mathrm{~kg} / \mathrm{ha}$ of potassium. Biberdzic et al. (2012), point out that the production of triticale on acid soils is most economically organized with the use of a combination of NPK, lime and organic fertilizers, as well as the use of NPK fertilizers with an increased dose of phosphorus. The most frequently applied quantities of nitrogen in Serbia ranged from 80 to $120 \mathrm{~kg} / \mathrm{ha}$ depending on the agrochemical properties of the soil (Biberdzić et al., 2017; Đekić et al., 2018; Lalević et al., 2019).

According to the literature, there are significant variations in terms of chemical composition and nutritional properties of triticale, which is a consequence of the existence of a large number of genotypes with very different properties. In terms of technological quality of grain, triticale still falls behind wheat for human nutrition (lower content and poorer quality of gluten), so it is mostly used for domestic animal nutrition (Perišić et al., 2019). As triticale grain has a high protein content (2-3\% more than wheat) and a very favorable amino acid composition, it is very suitable as a nutrient (Đekić, 2010). Changes in protein and grain mass in some cereals depend on the location of the grain in the class. Milovanović et al. (2007a), describing the variety of triticale Knjaz of Kragujevac, they have point out that its average content of crude protein in $\mathrm{cm}$ was $14.1 \%$, which was $1.2 \%$ more than the standard $(\mathrm{Kg} 20)$. The protein content in the grain of Kragujevac varieties usually varies in the range of 14 to $17 \%$ (Milovanović et al., 2007b). The same authors have pointed out that the Kg Rubin variety has an average mineral content of $1.82 \%$ in the grain.

Perišić et al. (2008), compared to the older varieties of triticale, the General variety is characterized by a higher and more stable yield. In a two-year period, the General variety achieved a statistically highly significant and higher grain yield $(6.78 \mathrm{t} / \mathrm{ha})$ compared to the standard of $\operatorname{Kg} 20 \quad(5.77 \mathrm{t} / \mathrm{ha})$. The authors concluded that the General variety has been an excellent component of feed mixtures and can partially or completely replace other nutrients (corn, barley, oats). According to the data collected during the test, the protein content of the tested varieties of triticale $\mathrm{Kg} 20$ and Triumph varied in the range from 11.36 to $14.12 \% \mathrm{~cm}$. The Triticale Triumph variety had a higher average 
protein content than the $K g 20$ variety (12.90 and $12.24 \% \mathrm{~cm}$ in the same order). Based on that fact, the grain of the Triumph variety can be said to have a relatively high protein content $(12.90 \% \mathrm{~cm})$ of high nutritional value and can be characterized by good physical and chemical properties (Đekić, 2010). Triticale has a relatively high content of proteins, which are important for the biological value and technological quality of products intended for both human and domestic animal nutrition (Đekić et al., 2014a). There are significant variations in terms of chemical composition and nutritional properties of triticale, which is a consequence of the existence of a large number of hybrids with very different properties (Đekić, 2010).

The obtained results from the research of Djekic et al. (2011) confirm that newer varieties and lines of winter triticale have lower protein content in the grain compared to the standard (KG 20), except for Favorit, Vojvoda, Tr 102/6, Tr 71/5-2 and Tr 110/3-2. Compared to wheat (Pobeda), they have lower protein content in the grain, except for the Favorit variety $(13.87 \% \mathrm{sm})$. The difference between the significance of the average values of grain protein content of the examined cultivars and triticale lines with the standard cultivar KG 20 was not significant $(\mathrm{P}>0.05)$. The values of protein content in this research period are significantly lower than the values from previous studies (Milovanovic et al., 2009 b, 2011), which is a result of year conditions and tendencies to decrease protein content in triticale due to continuous selection pressure to increase yields and grain bulk improvements. Djekic et al. (2011) found that the protein content ranged from 13,074 to $14,694 \%$ DM. They found that there were no statistically significant differences in the average values of protein content between the examined varieties of spring triticale and promising genotypes in relation to the standard variety Vojvoda. The average protein content of the cultivar Knjaz (14.694\%) shows a statistically significant difference in relation to the cultivar Vojvoda. All this indicates that the genotypes of spring triticale have a higher protein content compared to winter.

Examining the chemical properties of grains of two Canadian winter varieties of triticale Pika and Bobcat, Salmon et al. (2002), observed that the Pika variety had a higher protein content of $13.1 \%$ than the Bobcat variety $(12.9 \% \mathrm{sm})$, while the higher fat content $(1.78 \% \mathrm{sm})$ and starch content $(55.36 \% \mathrm{sm})$ had the Bobcat variety.

The content of protein and mineral substances are correlated, which means that an increase in the content of protein in the grain probably increases the content of minerals in it (Djekic et al., 2011). The nutritional value of protein depends on the content of essential amino acids (Perišić et al., 2019).

\section{Application of triticale in poultry nutrition}

Triticale is mostly used as animal feed. Numerous studies indicate that triticale successfully replaces a part of corn, wheat or barley in animal feed without negative consequences on the effect of domestic animals (Đekić, 2010). Triticale is a suitable nutrient for all types of animals because it is a high source of energy. Triticale is already widely used to feed poultry (broilers) worldwide (Johnson and Eason, 2006; De Brum et al., 2000). The nutritional 
value of triticale on the production traits of heavy line hybrids (food consumption, body weight at the beginning and end of the trial period, mortality and food conversion) has been studied by a large number of researchers (Hermes and Johanson, 2004), while there were no similar researches in our country.

Camiruaga et al. (2001) examined the production characteristics of broiler chickens that were fed with a mixture based on corn or triticale. The experiment was conducted on broilers of the heavy line hybrid Hubbard. The diet was based on corn or triticale (D1 and D2) which were used in different concentrations. Two hundred and forty-day-old broiler chickens up to 28 days of age were fed with 8 different treatments (T1-T8). Treatments with odd numbers are composed on the basis of corn and treatments with even numbers on the basis of triticale. T1 and T2 had no added enzymes, T3 and T4 were with the addition of cellulose, protease and phytase; T5 and T6 with B-glucanase and phytase, and T7 and T8 received phytase only. At the end of the experiment, two chickens from each group were slaughtered to determine slaughter values. T6 group chickens had the highest body weight. The chickens of the $\mathrm{T} 7$ group had significantly positive differences in relation to $\mathrm{T} 1$, which indicates the influence of phytase in the corn grain. They found that slaughter yields ready for roasting ranged from 75 to $77 \%$, with the T6 group chickens having the highest yield. Korver et al. (2004) show that triticale has great potential as a feed material for chickens, as it could replace wheat in broiler fattening mixtures, which would further reduce the cost of food production by about $5 \%$. The authors concluded that by replacing wheat with triticale in the broiler fattening mixture, there are no significant changes in the production and slaughter characteristics of chickens, that the body weight of chickens fed with triticale, as well as mortality and food consumption do not differ significantly from the same characteristics in chickens which are fed with wheat.

The research was conducted to determine the best level of replacement of corn with triticale in broiler fattening mixtures. De Brum et al. (2000) examined 1,560 one-dayold chicks, male and female, which were used in the study from 1 to 42 days of age. The experiment was performed according to a randomized block system with five treatments: $0,25,50,75 \%$ replacement of corn with triticale, and the fifth treatment contains mainly triticale and soy flour. At the end of the experiment, 12 chickens, six male and six female chickens were slaughtered. In the first phase of the experiment, there were significant differences between the sexes for all examined treatments in food consumption and conversion. Male chickens performed better than females.

Barneveld and Cooper (2002) examined six varieties of triticale in broiler feed mixtures. The total food consumption for one kilogram of chicken body weight varied from 1.75 to $2.24 \mathrm{~kg}$. They point out that the grain of triticale had a higher content of protein, lysine and methionine, while the digestibility was the same as that of grain of wheat and corn. Shakouri and Kermanshahi (2003) examined seven varieties of wheat and a variety of triticale in the preparation of mixtures for broiler fattening. 3 groups of chickens were examined, the first, which was fed with $60 \%$ corn in the mixture, the second with $60 \%$ wheat and the third with $60 \%$ triticale in the mixture for broiler fattening. The content of total proteins in wheat grain ranged from 9.19 to $13.68 \%$, and in triticale $13.15 \%$. 
Consumption of food in the first group of chickens in the period from 1-14 days ranged from $416-438 \mathrm{~g}$, in the second group 406-427 $\mathrm{g}$ and in the third 427-430 $\mathrm{g}$. Feed conversion in the examined chickens in the same period of age was $1.65-1.69 \mathrm{~g} / \mathrm{g}$ (I), 1.62-1.80 g/g (II) and $1.73-1.89 \mathrm{~g} / \mathrm{g}$ in the third groups. In order to investigate the effects of corn, wheat and triticale on the performance and digestive characteristics of broiler chickens Shakouri and Kermanshahi (2007), conducted an experiment on 288 roosters up to 57 days of age. Chickens fed with wheat and triticale had a significantly lower feed conversion. The body weight of chickens fed with wheat with the addition of enzymes did not differ from the weight of chickens fed only with corn and triticale. The stomachs of chickens fed with wheat and triticale were heavier than those of chickens from other treatments.

Comparing triticale and wheat in the diet of broilers Korver et al. (2004), prefer triticale due to higher average weekly growth of chickens, with the same amount of food intake. The same authors, examining two groups of chickens: the first group-wheat and the second group-triticale came to the conclusion that the body weight of chickens fed with triticale at the end of the experimental period was $2.11 \mathrm{~kg}$, while the first group had a body weight of $2.10 \mathrm{~kg}$. Higher mortality was noticed in the first group of chickens $5.5 \%$. Hermes and Johanson (2004) claim that triticale in the diet of heavy line hybrids, which participated in different amounts in the broiler fattening mixture, did not show negative effects on the production characteristics of chickens. The highest body weight of the tested chickens was achieved with a $10 \%$ share of triticale in broiler fattening mixtures, while a higher feed conversion was achieved with the formulation with a $15 \%$ share of triticale. Sarker et al. (2006), concluded that the highest body weight at the end of the experimental period was achieved by chickens fed with the following formulations: $\mathrm{W}_{40} \mathrm{~T}_{60}$ and $\mathrm{W}_{60} \mathrm{~T}_{40}$. The lowest mortality was determined in the formulation $\mathrm{W}_{100} \mathrm{~T}_{0}$, in a mixture without triticale. A study of 576 male broiler chickens (Cobb 500) with an initial body weight of $41.5 \mathrm{~g}$ that were included in the feeding experiment was performed by Jozefiak et al. (2007). The study consisted of six treatments in 12 wire floor cages ( 72 cages) with 8 chickens in each cage. Throughout the experimental period (1-35 days), chickens were given a mixture based on triticale-variety Presto, rye-variety Dankowskie Zlote or wheat-variety Cobra, which were fed with adlibitum starter mixture (1-14 days) and grower mixture (15-35 days). The best results were achieved by chickens fed with triticale. The body weight of broilers at 35 days of age that were fed with triticale varied from $1.54-1.61 \mathrm{~kg}$, in the group fed with rye from $0.81-1.14 \mathrm{~kg}$, while the group of chickens fed with wheat had a weight in the range of $1.49-1.50 \mathrm{~kg}$.

The share of triticale with $65 \%$ in the broiler fattening mixture up to 21 days of age was investigated by Pourreza et al. (2007). The tests were performed on Ross hybrid chickens. Based on the obtained data, the authors concluded that the body weight of chickens at 21 days of age that were fed with triticale was $477.4 \mathrm{~g}$; food conversion $1.60 \mathrm{~kg} / \mathrm{kg}$; daily food consumption per chicken $34.0 \mathrm{~g} /$ hour/day. Three different treatments of broiler diet (T1control, T2-triticale and T3-whole grain triticale) in broiler diet were examined by Santos et al. (2007). At the end of the experimental period, the chickens of the T2 experimental group fed with ground triticale $(2.83 \mathrm{~kg})$ had the highest body weight, and the smallest 
chickens were fed with whole grain of triticale $(2.68 \mathrm{~kg})$. Chickens of the third group (1.85 $\mathrm{kg} / \mathrm{kg}$ ) had the highest feed conversion during the experiment, and chickens of the second group $1.77 \mathrm{~kg} / \mathrm{kg}$ had the lowest. Santos et al. (2008), tested 2.561 one-day-old Ross 508 hybrid chickens. The experiment consisted of 4 dietary meals with 40 broiler chickens per group. Dietary treatments were throughout the experimental period (from the 1 to 42 day). From the 1 to the 14 day, the chickens of the experimental group were fed with a starter mixture with $58.04 \%$ triticale (22\% protein), from 15 to 28 day grower mixture with $64.71 \%$ triticale (20\% protein) and from 29 to 42 they were given a finisher mixture with $70.97 \%$ triticale (18\% protein). The first group of chickens was fed with a mixture with corn, the second with a mixture with whole grain corn, the third with triticale and the fourth with whole grain triticale in the mixture. The chickens of the first group had the highest body weight on the 14 and 28 day of age (405.2 $\mathrm{g}$ and $1.46 \mathrm{~kg}$ ), while on the $42 \mathrm{nd}$ day of age the chickens of the third experimental group fed with ground triticale had the highest body weight $(2.87 \mathrm{~kg})$. Chickens of the third group $(1.74 \mathrm{~kg} / \mathrm{kg})$ had the highest feed conversion during the experiment.

Triticale is an excellent component for preparing feed mixtures, due to its high content of amino acids and proteins, and it can partially or completely replace other or more expensive nutrients. Đekić et al. (2012a) made a comparison between chickens fed with mixtures containing and chickens fed with mixtures that contained triticale. Based on the obtained data, the authors concluded that there were statistically significant differences only in feed conversion in the examined chickens, while there were no significant differences in body weight, although chickens fed with a mixture of triticale had a slightly higher body weight at the end of fattening. Examining triticale as a nutrient in the diet of broiler chickens, Đekić et al. (2012b) found that there are very significant differences between the average body weight of chickens between K-group chickens that were fed with standard mixture and O-II group fed with triticale variety Favorit and O-I chickens fed with triticale variety $\mathrm{Kg} 20$ and O-I groups. This points to the conclusion that the average body weight of O-II group of chickens before slaughter on the $42^{\text {nd }}$ day of fattening will be in $99 \%$ of cases $0.099 \mathrm{~kg}$ higher than the K-group and $0.116 \mathrm{~kg}$ higher than the O-I group of chickens.

An important research was conducted by Đekić et al. (2014b), who examined the influence of triticale as a feed on the production and slaughter characteristics of broiler chickens. The research was conducted on 200 chickens for fattening, two groups, the first was control group (classic mixture) and the second experimental group (mixture with triticale $\mathrm{Kg} \mathrm{20}$ ). In male chickens from the control group, the weight of thigh (259.717 g) was slightly higher than the weight of thighs of chickens of the same sex from the experimental group ( $243.250 \mathrm{~g}$ ), while female chickens from the experimental group $(237.100 \mathrm{~g})$ had a significantly higher weight of thigh to chickens of the same sex from the control group $(198.273 \mathrm{~g}),(\mathrm{P}<0.01)$. In addition to weight, it is significant that the proportion of abdominal fat was lower in the examined groups of chickens of both sexes that were fed with triticale. The weight of meat of chicken drumsticks of male, female and both sexes from the experimental group $(173.933 ; 165.917$ and 
$169.925 \mathrm{~g}$ ) was higher than the weight of chicken drumstick meat from the control group $(172.400 ; 159.617$ and $166.008 \mathrm{~g})$, but in the samples of meat of the drumsticks of female chickens, the difference was significant.

Đekić et al. (2015) examined how triticale in feed mixtures for broiler fattening affects the growth, production and slaughter characteristics of broiler chickens. The research was performed on 400 chickens for fattening, provenance Ross 308. On that occasion, four groups or treatments were formed, with 100 chickens in each group. The first group was fed with the classic broiler fattening mixture (starter, grower I, grower II and finisher) and served as a control group. Other groups of chickens were fed with mixtures containing $7.5 \%, 12 \%, 15 \%$ and $18 \%$ triticale. So, four groups of broiler chickens were formed, with 100 broiler chickens in each group, control group fed with a classic mixture for broiler fattening, B-group (fed with a mixture containing triticale of genotype $\mathrm{Kg} \mathrm{20}$ ), C-group (fed with the triticale Favorit) and D-group (fed with the triticale Triumph). The experiment of feeding the chickens lasted 49 days. During the $49^{\text {th }}$ day, the body weight of chickens from the experimental C-group fed with the variety of Favorit was higher by $6.59 \%$, compared to the control group, while the body weight of chickens from the D-group fed with variety of triticale Triumph, had a higher body weight by $2.02 \%$, than chickens fed with a mixture without triticale. The best results in the body weight of chickens before slaughter, weight of chickens ready for roasting and ready for grilling were achieved by broiler chickens in C-group after 49 days of age.

Given the above results (Djekic et al., 2011; Đekić, 2010; Đekić et al., 2012b; 2014b), it can be said that the obtained values related to body weight and weight gain, fit into the general conclusion, that tririkale added to chicken feed, does not negatively affect the absorption of nutrients from the experimental mixture. The authors concluded that triticale can very successfully replace wheat and in broiler feed rations, because the food needs in the world are increasing, and the areas under wheat are decreasing.

\section{Application of triticale in pig nutrition}

Triticale is mostly used as animal feed. Numerous studies indicate that triticale successfully replaces a portion of corn, wheat, or barley in pig feed mixtures without negative effects on their performance (Coffey and Gerrits, 2009). The possibility of using triticale in the diet of pigs was studied by Kovcin and Stanacev (2004). Based on a review of literature data, they point out that triticale can be included in pig feed mixtures up to $60 \%$ of the total amount of cereals. Further increase of triticale in piglet mixtures leads to a decrease in growth. Also, the amount of trypsin and chymotrypsin inhibitors in older varieties of triticale is quite high, which negatively affects the use of this nutrient in the diet of pigs.

The influence of triticale levels in the diet of chosen piglets was investigated by Erickson et al. (1979). The authors examined the different participation of triticale in the diet of chosen piglets in the following quantities: $0,20,40,60,80$ and $100 \%$ of total cereals. Based on the obtained data, they concluded that the increase of triticale in the diet of 
chosen piglets above $60 \%$, leads to a decrease in growth, while food consumption is higher. However, if synthetic lysine is included in the mix, a further increase in triticale of up to $100 \%$ is possible, stopping the decline in piglet growth, but increasing food consumption, which is justified by the high proportion of cellulose. Triticale in the initial stages of fattening pigs has similar nutritional properties as, but in the final stage of fattening Mayer and Barnett (2008) give preference to. In addition to, triticale is very successfully replaced by soy flour in pig feed mixtures.

Mayer and Barnett (2008) point out that the content of the amino acid lysine in pig fattening mixtures is more important than the content of crude protein, because examining mixtures with and without triticale with the same crude protein content, found that pigs fed with the mixture which contains triticale have higher growth and meat yield. Sullivan et al. (2007) examined three groups of piglets that were fed in the summer and winter months. The first group of pigs was fed with a standard mixture without the participation of triticale, the second contained $40 \%$ triticale and the third contained $80 \%$ triticale. The authors concluded that food consumption in the summer months was higher compared to the winter months and that the lowest food consumption per unit of growth was in the group fed with $40 \%$ triticale. Studies that were conducted in Canada using triticale in pig nutrition (Robertson et al., 1999) indicate that and barley grain can be successfully replaced with triticale grain in pig breeding mixtures of $25-110 \mathrm{~kg}$.

\section{Economic significance of triticale}

The concept of sustainable development of agriculture implies an integrated system of agriculture, whose basic task is to achieve economic, environmental and social goals, which are often opposite and contradictory. Agriculture is an activity in which natural resources and the natural environment are used to implement the principles of sustainable development, which farmers themselves shape through their activities (Marks-Bielska, 2019). Profitability of modern agricultural systems is not possible without reducing agricultural inputs. By comparative analysis of input and output, we can assess the efficiency of technology and the effectiveness of farm management. (Pozubenkova and Galiullin, 2019). Haliniarz et al. (2018) point out that the analysis of economic effects in the technology of spring wheat production indicates a clear advantage of lower intensity technology in relation to more intensive technologies. This is primarily due to high costsof mineral fertilizer that could not be compensated by the obtained yields. Bielski and Falkovski (2017) stated that in the production of winter triticale, mineral fertilization has the largest share and ranges from 30.3 to $61.5 \%$ of direct costs. Kadakoglu et al. (2021), also conclude that mineral fertilization accounts for the largest share of direct costs. Other authors point out that high production efficiency can be achieved by using environmentally friendly agricultural methods and processing methods, which are less harmful to the environment (Bielski, 2014; Marks-Bielska, 2019; Pozubenkova and Galiullin, 2019). An analysis of two neighboring farms, Kołosovski and Dobek (2016), found that the application of manure increases the cost of winter triticale production. 
The farm in which slurry was used, achieved a higher yield of winter triticale, which influenced the realization of a better financial result of the farm. As product quality is a very important factor, the decision on the choice of production technology must be based on the characteristics of the quality of manufactured products (Đekić et al., 2014a; Terzić et al., 2018; Rajičić et al., 2020a).

In order to demonstrate the competitive advantage of agricultural holdings, products or technologies, production costs and gross margin are used for comparison (Bielski, 2014). Pozubenkova and Galiullin (2019), point out that it is the production cost of winter triticale per unit in the 2015 year is 360.8 rubles, in the 2016 year 338.08 rubles and in the 2017 year 337.33 rubles and tends to decline. The same authors point out that when marketing costs are taken into account, the costs for $100 \mathrm{~kg}$ of winter triticale reach almost 362 rubles. By increasing costs and sales to a level higher than 30 and $43 \%$, the company would make a profit of more than 2 million rubles by the third year by producing and selling winter triticale grains. Kadakoglu et al. (2021), find that the farms earned of the total triticale gross production value $8.58 \%$ from by-product income and 7.34\% from agricultural support income. Bielski and Falkovski (2017) point out that the best economic indicators are achieved by applying the highest yield technologies. Profitability of production depends on the price of grain and the ratio of price and cost of production. Kołosovski and Dobek (2016) stated that a farm that used manure made higher profits, which led to an increase in economic efficiency by an average of 0.1 . Kadakoglu et al. (2021), find that the relative profit value refers to the production value of 1.22 units in return for 1.00 unit expenditure for triticale production. The same authors point out it was determined that as the triticale production areas increase, the relative profit value also increases.

\section{Conclusion}

Triticale is a type of cereal created by crossing wheat and rye. Thanks to the nutritional values higher than, breeders and livestock nutrition experts have so far recommended it in the diet of all types of domestic animals. Also, it can very successfully replace wheat in meals for animal nutrition, because the needs for food in the world are increasing, and the yields and areas under wheat are decreasing. It is especially distinguished by the high protein content in the grain and the more favorable content of essential amino acids compared to other cereals. Based on all the above, it can be concluded that triticale, as the youngest type of small grain, has found its place in farming, and its quality has also improved in livestock production. It is increasingly present in the human diet. All of the above gives it the right position as one of the promising plants of the future.

\section{Acknowledgements}

This paper is part of the project, Grant number 451-03-09/2021-14/200383, financed by the Ministry of Education, Science and Technology Development of Republic of Serbia. 


\section{Conflict of interests}

The authors declare no conflict of interest.

\section{References}

1. Barneveld, R.J., \& Cooper, K.V. (2002). Nutritional quality of triticale for pigs and poultry. Proceedings of the $5^{\text {th }}$ International Triticale Symposium, Poland, 1, 277-282.

2. Benbelkacem, A. (2002). Development and use of triticale (x Triticosecale Wittmack) in eastern Algeria. Proceedings of the $5^{\text {th }}$ International Triticale Symposium, Poland, 1, 283-286.

3. Biberdžić, M., Maksimović, G., Barać, S., \& Jovović, Z. (2012). Economic effects of triticale production on acid soils. Economic of Agriculture, 59(4), 579-587.

4. Biberdžić, M., Barać, S., Prodanović, D., Đikić, A., Đekić, V., \& Lalević, D. (2017). Impacts of liming and fertilization on yield of two triticale varieties. Proceedings of the VIII International Scientific Agriculture Symposium “Agrosym 2017”, 05-08 October, Jahorina, East Sarajevo, Republic of Srpska, BiH, 577-582.

5. Bielski, S. (2014). Economic efficiency of winter triticale grain production. Acta Scientiarum Polonorum. Oeconomia, 13(2), 17-23.

6. Bielski, S., \& Falkowski, J. (2017). Effect of the nitrogen and magnesium fertilization on yield and economic efficiency of winter triticale production. In Proceedings of the 8th International Scientific Conference Rural Development, Akademija, Lithuania, 23-24 November 2017, 17-23.

7. Bielski, S., Romaneckas, K., \& Šarauskis, E. (2020). Impact of nitrogen and boron fertilization on winter triticale productivity parameters. Agronomy, 10, 279.

8. Camiruaga, M., Garcia, F., Elera, R., \& Simonetti, C. (2001). Respuesta Productiva de Pollos Broilers a la Adición de Enzimas Exógenas a Dietas Basadas en Maiz o Triticale. Enero-Marzo, 28(1), 1-59.

9. Coffey, M.T., \& Gerrits, W.J. (2009). Digestibility and feeding value of b858 triticale for swine. Journal Animal Science, 66, 2728-2735.

10. De Brum P.A.R., Zannoto D.L., Gvidoni A.L., Rosa P.S., De Lima G.J.M.M., \& Viola E.S. (2000). Triticale in diets for broilers. Pesquisa Agropecuaria Brasileira, 35(2), 229-239.

11. Derejko, A., Studnicki,M., Wójcik-Gront, E., \& Gacek, E. (2020). Adaptive Grain Yield Patterns of Triticale ( $\times$ Triticosecale Wittmack) Cultivars in Six Regions of Poland. Agronomy, 10, 415. doi:10.3390/agronomy10030415.

12. Djekic, V., Mitrovic, S., Milovanovic, M., Djuric, N., Kresovic, B., Tapanarova, A., Djermanovic, V., \& Mitrovic, M. (2011). Implementation of triticale in nutrition of non-ruminant animals. African Journal of Biotechnology, 10(30), 5697-5704. 
13. Djekic, V., Pandurevic, T., Mitrovic, S., Radovic, V., Milivojevic, J., \& Djermanovic, V. (2012). Nutritional value of triticale (Trijumf) for broiler diets. Proceedings of the “Agrosym Jahorina 2012”, November 15-17, Jahorina, 548-553.

14. Đekić, V. (2010). Uticaj načina proizvodnje tritikalea na efikasnost krmne smeše u ishrani brojlerskih pilića. Doktorska disertacija, 1-90. Univerzitet u Beogradu, Poljoprivredni fakultet-Beograd. [in English: Đekić, V. (2010). Effect of triticale production modality on efficiency of feeding mixtures nutrition in broiler chickens. PhD thesis, 1-90. University of Belgrade, Faculty of Agriculture-Belgrade].

15. Đekić, V., Mitrović, S., Radović, V., Đermanović, V., \& Obradović, S. (2012a). Effect of feeding different triticale on broiler performance. Proceedings of the first international Symposium on animal science. November 8-10, Belgrade, Serbia, Book I, 665-671.

16. Đekić, V., Mitrović, S., Šefer, D., Obradović, S., \& Vukašinović, M. (2012b). The effect of different varietes of triticale on the product characteristics in broiler chickens. Veterinarski glasnik, 66(5-6), 345-353.

17. Đekić, V., Milovanović, M., Popović, V., Milivojević, J., Staletić, M., Jelić, M., \& Perišić, V. (2014a). Effects of fertilization on yield and grain quality in winter triticale. Romanian Agricultural Research, 31, 175-183.

18. Đekić, V., Mitrović, S., Radović, V., Obradović, S., Đermanović, V., Mitrović, M., \& Pandurevic, T. (2014b). Effect of use of triticale on yield and meat quality of broiler chikens. Meat technology, 55(1), 39-45.

19. Đekić, V., Mitrović, S., Radović, V., Obradović, S., Đermanović, V., Mitrović, M., \& Pandurević, T. (2015). Effect of feeding triticale on performance of broiler chicks. Agriculture \& Forestry, 61(1), 279-286.

20. Đekić, V., Milivojević, J., \& Branković, S. (2018a). The interaction of genotype and environment on yield and quality components in triticale. Biologica Nyssana, 9(1), 45-53.

21. Đekić, V., Milivojević, J., Popović, V., Terzić, D., Branković, S., Biberdžić, M., \& Madić, M. (2018b). The impact of year and fertilization on yield of winter triticale. Proceedings of the 22th International ECO-Conference and 10th Eco-Conference on safe food. Novi Sad, Serbia, 26-28 September, 125-134.

22. Đekić, (Rajičić), V., Popović, V., \& Terzić, D. (2019). Production and Quality Components of Winter Triticale in Semi-Arid Conditions. Nova Science Publishers, Monograph, Chapter 6. (Ed.) Igor Janev, 149-170.

23. Đurić, N., Trkulja, V., Prodanović, S., \& Sabovljević, R. (2011). Oplemenjivanje ozimog tritikalea PKB Vožd stvorenog u Institutu PKB Agroekonomik. Zbornik naučnih radova Instituta PKB Agroekonomik, 17(1-2), 43-47. [in English: Đurić, N., Trkulja, V., Prodanović, S., \& Sabovljević, R. (2011). Breeding winter triticale PKB Vožd created in the institute PKB. Proceedings of research papers, 17(1-2), 43-47.]. 
24. Đurić, N., Trkulja, V., Cvijanović, G., \& Đekić, V. (2015). Nova sorta ozimog tritikalea PKB Kardinal stvorenog u Institutu PKB Agroekonomik. Zbornik naučnih radova Instituta, 21(1-2), 95-100. [in English: Đurić, N., Trkulja, V., Cvijanović, G., \& Đekić, V. (2015). New winter triticale species Kardinal, created in Institute PKB Agroekonomik . Proceedings of research papers, 21(1-2), 95-100.].

25. Erickson, J.P., Miller, E.R., Elliott, F.C., Ku, P.K., \& Ullrey, D.E. (1979). Nutritive evaluation of triticale in swine starter and grover diets. Journal of Animal Science, 48, 547-553.

26. Haliniarz, M., Nowak, A., Woźniak, A., Sekutowski, T.R., \& Kwiatkowski, C.A. (2018). Production and Economic Effects of Environmentally Friendly Spring Wheat Production Technology. Polish Journal of Environmental Studies, 27(4), 1523-1532.

27. Hermes, J.C., \& Johanson, R.C. (2004). Effects of Feeding Varios Levels of Triticale var. Bogo in the Diet of Broiler and Layer Chickens. Journal of Applied Poultry Research, 13(4), 667-672.

28. Ivanova, A., \& Tsenov, N. (2014). Production potential of new triticale varieties grown in the region of Dobrudzha. Agriculture Science Technology, 6, 243-246.

29. Johnson, R., \& Eason P. (2006). Evaluation of triticale for use in meat-type chickens. Journal of Science and Food Agriculture, 42, 95-108.

30. Kadakoglu, B., Karli, B., Gül, M., \& Özuygur, A. (2021). Economic analysis of triticale production: a case study of Corum province, Turkey. Management, Economic Engineering in Agriculture \& Rural Development, 21(3), 483-490.

31. Kendal, E., Sayar, M.S., Tekdal, S., Aktas, H., \& Karaman, M. (2016). Assessment of the Impact of Ecological Factors on Yield and Quality Parameters in Triticale Using GGE Biplot and AMMI Analysis. Pakistan Journal of Botany. 48(5): 1903-1913.

32. Kirchev, H., \& Georgieva, R. (2017). Genotypic plasticity and stability of yield components in triticale (x Triticosecale Wittm.). Scientific Papers. Series A. Agronomy, 60, 285-288.

33. Kołosowski, P., \& Dobek, T.K. (2016). Comparison of economic efficiency related to the production of winter triticale in farms which use different variants of fertilization. Journal of Research and Applications in Agricultural Engineering, 61(3), 233-235.

34. Korver, D.R., Zuidhof, M.J., \& Lawes, K.R (2004). Performance Characteristics and Economic Comparison of Broiler Chickens Fed Wheat and Triticale-Based Diets. Poultry Science, 83(5), 716-725.

35. Kovcin, S., \& Stanacev, V. (2004). Triticale in the nutrition of pigs. Acta Agriculturae Serbica, 9(17), 625-631.

36. Lalević D., Biberdžić M., Jelić M., \& Barać S. (2012). The characteristics of triticale cultivated in rural areas. Agriculture \& Forestry, 58(2), 27-34.

37. Lalevic, D., \& Biberdzic, M. (2016). Effects of rates of nitrogen on yield and yield components of winter triticale. Journal of Agriculture and Science, 61, 127-135. 
38. Lalević, D., Biberdžić, M., Ilić, Z., Milenković, L., Tmušić, N., \& Stojiljković, J. (2019). Effect of cultivar and increased nitrogen quantities on some productive traits of triticale. Agriculture \& Forestry, 65, 127-136.

39. Madić, M., Paunović, A., Djurović, D., Marković, G., Knežević, D., Jelić, M., \& Stupar, V. (2018). Grain yield and its components in triticale grown on a pseudogley soil. Journal of Central Europen Agriculture, 19, 184-193.

40. Marks-Bielska, R., Bielski, S., Novikova, A., \& Romaneckas, K. (2019). Straw stocks as a source of renewable energy. A case study of a district in Poland. Sustainability, 11, 4714.

41. Milovanovic, M., Perisic, V., \& Staletic, M. (2006). Favorit-nova sorta pzimog tritikalea za intenzivne uslove gajenja. Zbornik radova Visoke tehničke škole u Požarevcu, 1-2, 93-97. [in English: Milovanovic, M., Perisic, V., \& Staletic, M. (2006). Favorit-new winter triticale cultivar for intensive growing conditions. Proceedings of Articles from the Technical Vocational College in Pozarevac, 1-2, 93-97.].

42. Milovanovic, M., Perisic, V., Staletic, M.,, Milivojevic, J., Zivanovic-Katic, S., \& Djekic, V. (2007a). Sorta ozimog tritikalea Knjaz. Zbornik radova Visoke tehničke škole u Požarevcu, 1, 13-18. [in English: Milovanovic, M., Perisic, V., Staletic, M., Milivojevic, J., Zivanovic-Katic, S., \& Djekic, V. (2007a). Variety of Winter Triticale Knjaz. Proceedings of Articles from the Technical Vocational College in Pozarevac, 1, 13-18.].

43. Milovanovic, M., Perisic, V., Djekic, V., \& Stevanovic, V. (2007b). KG Rubinnova sorta tritikalea. Zbornik radova Visoke tehničke škole u Požarevcu, 1, 19-23. [in English: Milovanovic, M., Perisic, V., Djekic, V., \& Stevanovic, V. (2007b). KG Rubin-New Triticale Cultivar. Proceedings of Articles from the Technical Vocational College in Pozarevac, 1, 19-23.].

44. Milovanović, M., Perišić, V., Staletić, M., Kuzmanović, J., \& Vučković, M. (2009a). Žarko-perspektivna sorta ozimog tritikalea. Zbornik radova Visoke tehničke škole u Požarevcu, 1-2, 55-59. [in English: Milovanović, M., Perišić, V., Staletić, M., Kuzmanović, J., \& Vučković, M. (2009a). Žarko-perspective variety of winter triticale. Proceedings of Articles from the Technical Vocational College in Pozarevac, 1-2, 55-59.].

45. Milovanović, M., Perišić, V., \& Prodanović, S. (2009b). Rezultati i perspektive oplemenjivanja ozimog tritikalea u Kragujevcu. Zbornik radova Visoke tehničke škole u Požarevcu, 1-2, 61-68. [in English: Milovanović, M., Perišić, V., \& Prodanović, S. (2009b). Results and perspectives of winter triticale breeding in Kragujevac. Proceedings of Articles from the Technical Vocational College in Pozarevac, 1-2, 61-68.].

46. Milovanović, M., Staletić, M., Đekić, V., Nikolić, O., \& Luković, K. (2011). Seed production and contribution of $\mathrm{KG}$ varieties to biodiversity of small grains in the period 2006-2010. Economics of Agriculture, 2(58), 103-111. 
47. Milovanovic, M., Perishic, V., Staletic, M., Đekić, V., Nikolic, O., Prodanovic, S., \& Lukovic, K. (2014). Diallel Analysis of Grain Number per Spike in Triticale. Bulgarian Journal of Agricultural Science, 20(5). 1109-1115.

48. Myer, R.O., \& Barnett, R.D. (2008). Triticale Grain in Swine Diets. Reviewed March 2008. Visit the EDIS Web Site at http://edis.ifas.ufl.edu

49. Perisic, V., Milovanovic, M., \& Bratkovic, K. (2008). Nova sorta ozimog tritikalea-General. Zbornik radova Visoke tehničke škole u Požarevcu, 1-2, 59-64. [in English: Perisic, V., Milovanovic, M., \& Bratkovic, K. (2008). New Cultivar of Winter Triticale-General. Proceedings of Articles from the Technical Vocational College in Pozarevac, 1-2, 59-64.].

50. Perišić, V., Perišić V., Hadnađev, M., Đekić, V., Dapčević Hadnađev, T., Vuković, S., \& Vukajlović, F. (2019). Impact of diatomaceous earth on the rheological properties of the dough of wheat, triticale, and rye flour dough. Journal of Stored Products Research, 82, 91-97.

51. Pourreza, J., Samie, A.H., \& Rowghani, E. (2007). Effect of Supplemental Enzyme on Nutrient Digestibility and Performance of Broiler Chicks fed on Diets Containing Triticale. International Journal of Poultry Science, 6(2), 115-117.

52. Pozubenkova, E.I., \& Galiullin, A.A. (2019). Economic efficiency of winter triticale cultivation in agribusiness entities. Volga Region Farmland, 2, 43-47.

53. Rajičić, V., Popović, V., Perišić, V., Biberdžić, M., Jovović, Z., Gudžić, N., Mihailović, V., Đurić, N., Čolić, V., \& Terzić, D. (2020a). Impact of Nitrogen and Phosphorus on Grain Yield in Winter Triticale Grown on Degraded Vertisol. Agronomy, 10(6), 757. doi.org/10.3390/agronomy10060757

54. Rajičić, V., Terzić, D., Popović, V., Dugalić, M., Branković, S., Luković, K., \& Madić, M. (2020b): Genetic potential of winter triticale as a healthy safe food. Proceedings of the 24th International Eco-Conference and 11th Eco-Conference on safe food, 23-25 September, Novi Sad, Serbia, 151-159.

55. Robertson, W. M., Jaikaran, S., Jeremiah, L. E., Salmon, D. F., Aherne, F.X., \& Landry, S.J. (1999). Meat quality and palatability attributes of pork from pigs fed corn, hulless barley or triticale diets. Advances in Pork Production, 10, 35.

56. Salmon, D., Temelli, F., \& Spence, S. (2002). Chemical composition of Western Canadian triticale varieties. Proceedings of the 5th International Triticale Symposium, 2, 445-450.

57. Santos, F.B.O., Sheldon, B.W., Santos, Jr. A.A., Ferket, P.R., Lee M.D., Petroso, A., \& Smith, D. (2007): Determination of Ileum Microbial Diversity of Broilers Fed Triticale- or Corn-Based Diets and Colonized by Salmonella. Journal of Applied Poultry Research, 16: 563-573. 
58. Santos, F.B.O., Sheldon, B.W., Santos, Jr. A.A., \& Ferket, P.R. (2008). Influence of Housing System, Grain Type, and Particle Size on Salmonella Colonization and Shedding of Broilers Fed Triticale or Corn-Soybean Meal Diets. Poultry Science, $87,405-420$.

59. Sarker, N.R., Haque, M.E., Haque, K.S., Haque, Q.M.S., \& Waddington, S.R. (2006). Triticale fodder and grain utilization by dairy cattle and poultry in Bangladesh. International Maize and Wheat improvement Center, Uttara, Dhaka-1230, Proceedings of the $6^{\text {th }}$ International Triticale Symposium, 108-113.

60. Saulescu, N.N., Ittu, G., Balota, M., Ittu, M. \& Mustatea, P. (1988). Breading wheat for lodging resistance, earliness and tolerance to abiotic stresses. H.-J. Braun et. al. (Eds.), Whet: Prospects for Global Improvement, 181-188.

61. Shakouri, M.D., \& Kermanshahi, H. (2003). Effect of NSP Degrading Enzyme Supplement on the Nutrient Digestibility of Young Chickens Fed Wheat with Different Viscosities and Triticale. Journal of Agriculture and Science Technology, 5, 105-112.

62. Shakouri, M.D., \& Kermanshahi, H. (2007). Effect of Enzyme Supplement to Wheat and Triticale-Based Diets on Performance and Digestive Tract Characteristics of Broiler Chickens. Journal of Science and Technology, Agriculture and Natural Resourse, 11(40), 351-360.

63. Stallknecht, G.F., Gilbertson, K.M., \& Ranney, J.E. (1996). Alternative wheat cereals as food grains: Einkorn, emmer, spelt, kamut, and triticale. Progress in new crops. ASHS Press, Alexandria, VA, 156-170.

64. Sullivan, Z.M., Honeыman, M. S., Gibson, N.M., \& Ken, P.J (2007). Efects of the child based on triticale unishing pig performance and pork quality in deep-bedded stalls ring. Meat Science, 76, 428-437.

65. Terzic, D., Đekić, V., Jevtic, S., Popovic, V., Jevtic, A., Mijajlovic, J., \& Jevtic, A. (2018). Effect of long term fertilization on grain yield and yield components in winter triticale. The Journal of Animal and Plant Sciences, 28(3), 830-836.

66. The Food and Agriculture Organization of the United Nations (FAO), Retrieved from http://www.fao.org (September, 06, 2021) 